\title{
Electroanalysis of Mefenamic Acid in Pharmaceutical Formulation and Spiked Biological Fluids on Modified Carbon Nanotube Electrode
}

\author{
Abdolmajid Bayandori Moghaddam ${ }^{1}$, Ali Mohammadi ${ }^{2,3 *}$ and Somaye Mohammadi,4
}

${ }^{1}$ Department of Engineering Science, College of Engineering, University of Tehran, P.O. Box 11155-4563, Tehran, Iran

${ }^{2}$ Department of Drug and Food Control, Faculty of Pharmacy, Tehran University of Medical Sciences, Tehran, Iran

${ }^{3}$ Nanotechnology Research Centre, Faculty of Pharmacy, Tehran University of Medical Sciences, Tehran, P.O. Box 14155-6451, Iran

${ }^{4}$ Pharmaceutical Quality Assurance Research Center, Faculty of Pharmacy, Tehran University of Medical Sciences, Tehran, Iran

\begin{abstract}
The development of an electrochemical sensor for determination of mefenamic acid is the main purpose of this work. The determination was performed in pharmaceutical formulations, spiked urine and human plasma samples by multi-walled carbon nanotube-graphite/Ag (MWCNTs-G/Ag) electrode. Hence some voltammetric methods were investigated to determination of mefenamic acid. The dependence of peak currents and potentials on $\mathrm{pH}$ and voltammetric parameters was investigated for the optimization of electrochemical method. The porous structure of MWCNTs-graphite mixture improves the electroactive surface area. As a result, a remarkable increasing in the peak currents was observed. The prepared mixture displayed an electrocatalytic effect in anodic oxidation of mefenamic acid with a sensitivity augmentation. The best electrochemical response was obtained from square wave voltammetry with a sensitive peak at $0.68 \mathrm{~V}$ in $\mathrm{pH} 5$. The prepared electrode showed good standard calibration curves during 3 days over a wide concentration range with RSD values ranging from 1.6-8\%. The limits of quantification and detection were 50 and $16 \mathrm{ng} / \mathrm{mL}$, respectively.
\end{abstract}

Keywords: Carbon nanotube; Pharmaceutical formulation; Spiked biological fluids; Mefenamic acid

\section{Introduction}

Drug analysis has an important role on public health [1] and due to extensive use of non-steroidal anti-inflammatory drugs for their devastating effects on pains like: headache, post-operative, dental pain and some diseases including arthritis, sport injuries and other rheumatic diseases, many researches were done for developing of sensitive and rapid technique for the analysis of these drugs [2]. One of these drugs is mefenamic acid, 2-[(2,3-Dimethylphenyl) amino] benzoic acid [3]. Overdoses of mefenamic acid generate toxic metabolite accretion that causes severe hepatic necrosis, including morbidity and death in patients [4]. Due to the vital importance of mefenamic acid, it is essential to develop a simple, rapid and reliable technique for the determination of mefenamic acid. Spectrophotometric [5], solid phase extraction [6], atomic absorption spectrometry [7], NMR [8], chromatography [9-13] and flow injection spectrophotometry [14,15] are several analytical methods developed for the determination of mefenamic acid. Electrochemical techniques are extensively applied due to their sensitive properties and usually they do not require sample pretreatment that is time consuming and difficult $[16,17]$.

So, the purpose of this work is to develop a sensor utilizing electrochemical nanotechnology for determination of mefenamic acid by using the simple, inexpensive and reliable technique.

Some electrochemical investigation about mefenamic acid in both redox mechanism field $[1,18]$ and quantitative determination like voltammetry [19] were also reported. In recent years the modification of electrode substrates with various nanomaterials (e.g. carbon nanotubes and metal oxide nanoparticles) and composite materials has been reported [20-22]. Composite materials typically consist of two or more components that modify the surface of electrodes. There is clear that the potential for several differences in the preparation (the type of carbon, binder and presence of modifiers) can affect the selectivity and sensitivity of electrochemical response of the modified electrode. The binder can be taken a simple mineral oil [23,24], polymers [25], wax or epoxy [26], or ionic liquid [27]. Among the carbon allotropes, carbon nanotubes (CNTs) were many applied for modification of electrodes. CNTs have risen to significant importance in recent years and have been extensively examined as electrode modifiers. CNTs are potentially applicable in a various fields like: optics, electronics, analytical science and others. They gained significant attending in electrochemical sensors and biosensors for the making of electrodes [28]. They provided fast electron transfer kinetics and reduced reaction potential.

In the present study, the catalytic activity of MWCNTs-graphite mixture toward the oxidation of mefenamic acid is demonstrated. The results display that MWCNTs-G/Ag electrode shows an efficient electrocatalytic behavior in the electrooxidation of mefenamic acid that leads to a considerable improvement in its anodic peak current. It is successfully applied to achieve a high electroactive surface area for development of an electrochemical sensor to determination of mefenamic acid in pharmaceutical dosage forms and biological fluids. A good linear relationship has been found between the anodic peak current and mefenamic acid concentration in the range of 50-2000 ng/ $\mathrm{mL}$. The limits of quantification and detection were 50 and $16 \mathrm{ng} / \mathrm{mL}$, respectively.

*Corresponding author: Ali Mohammadi, Department of Drug and Food Control Faculty of Pharmacy, Tehran University of Medical Sciences, Tehran, Iran, E-mail: alimohammadi@tums.ac.ir

Received June 30, 2012; Accepted August 27, 2012; Published August 29, 2012 Citation: Moghaddam AB, Mohammadi A, Mohammadi S (2012) Electroanalysis of Mefenamic Acid in Pharmaceutical Formulation and Spiked Biological Fluids on Modified Carbon Nanotube Electrode. Pharmaceut Anal Acta 3:165. doi:10.4172/2153-2435.1000165

Copyright: (c) 2012 Moghaddam AB, et al. This is an open-access article distributed under the terms of the Creative Commons Attribution License, which permits unrestricted use, distribution, and reproduction in any medium, provided the original author and source are credited. 
Citation: Moghaddam AB, Mohammadi A, Mohammadi S (2012) Electroanalysis of Mefenamic Acid in Pharmaceutical Formulation and Spiked Biological Fluids on Modified Carbon Nanotube Electrode. Pharmaceut Anal Acta 3:165. doi:10.4172/2153-2435.1000165

\section{Experimental}

\section{Reagents and materials}

Mefenamic acid working standard powder was a gift from Iranian Quality Control Lab, Ministry of Health and Medical Education of Iran. Boric acid, phosphoric acid, acetic acid, sodium hydroxide, ethyl acetate, paraffin oil (density $0.84 \sim 0.89)$ and graphite powder $(<50$ $\mu \mathrm{m})$ were all provided from Merck. Multi-walled carbon nanotubes (MWCNTs) prepared by chemical vapor deposition were purchased from Neutrino Co. (Iran). The MWCNTs had an outer wall diameter distribution of $<10 \mathrm{~nm}$, a length of between $5-15 \mu \mathrm{m}$ and a special surface area of $180-190 \mathrm{~m}^{2} / \mathrm{g}$ and amorphous carbon $<3 \%$. All other chemicals were purchased from Merck and used without any further purification. Doubly distilled deionized water was used for all aqueous solution preparations. Britton-Robinson buffer containing $0.04 \mathrm{M}$ of each component (acetic acid, phosphoric acid and boric acid), adjusted to the required $\mathrm{pH}$ with sodium hydroxide solution $(0.2 \mathrm{M})$ and was used as supporting electrolyte. Mefenamic acid capsules, each of containing $250 \mathrm{mg}$ of active ingredient, were purchased from a local pharmacy. Fresh frozen plasma was obtained from Iranian Blood Research and Fractionation Holding Company (IBRFC). Drug free human urine was obtained from healthy volunteers (25-30 years). All experiments were carried out at an ambient temperature of $25 \pm 2^{\circ} \mathrm{C}$.

\section{Apparatus}

A three electrode cell was used for the electrochemical experiments, incorporated a hand-made working MWCNTs-G/Ag electrode using a $\mu$-AUTOLAB TYPE III. A saturated $\mathrm{Ag} / \mathrm{AgCl} / \mathrm{KCl}$ as a reference electrode and platinum wire that was used as a counter electrode. Sonication was achieved using of ultrasonic bath system TECNOGAZ, Tecna $6(50-60 \mathrm{~Hz}, 230 \pm 10 \% \mathrm{~V}, 0.138 \mathrm{KW})$. Furthermore, a Philips model X-30 scanning electron microscope (SEM) was used to obtain the microscopic image.

\section{Electrode preparation}

Due to our recent studies at investigation of CNTs-graphite mixture for electrochemical studies, different ratios of carbon nanotube and graphite were examined and the best results were obtained in ratio of $1: 1, \mathrm{w} / \mathrm{w}$ [26]. We found that MWCNTs-G/Ag electrode is useful for determination of mefenamic acid. So, we continued our studies on mefenamic acid by this electrode. In detail, $6 \mathrm{mg}$ from both MWCNTs and graphite were mixed together truly and small amount of paraffin oil $(3.6 \mu \mathrm{L})$ were added. Afterwards, a portion of the composite mixture was packed into the end of a polytetrafluoroethylene tube. The electrical contact was made by forcing an $\mathrm{Ag} \operatorname{rod}(\mathrm{r}=1 \mathrm{~mm})$ into the polytetrafluoroethylene tube and the composite to ensure that a layer of composite was formed on the surface of Ag electrode.

\section{Preparation of stock and standard solutions}

Mefenamic acid stock solution $(0.2 \mathrm{mg} / \mathrm{mL})$ was prepared by dissolving of mefenamic acid working standard powder in ethanol. Mefenamic acid standard solutions with different concentrations were obtained by diluting the specified volume of stock solution. The solutions were stored in refrigerator at $4^{\circ} \mathrm{C}$ for maximum three days. Plasma/urine standard solutions (200, 500 and $1000 \mathrm{ng} / \mathrm{mL}$ ) were prepared by spiking the appropriate amounts of mefenamic acid stock solution with the blank plasma/urine samples.

\section{Extraction procedure}

In this part, $1.0 \mathrm{~mL}$ of buffer solution $(\mathrm{pH} 2.5)$ was added to $0.5 \mathrm{~mL}$ spiked plasma or urine, then the mixture was vortexed for 2 min and afterwards $2 \mathrm{~mL}$ ethyl acetate was added and vortexed for 3 minutes. The mixture was centrifuged at $6000 \mathrm{rpm}$ for $5 \mathrm{~min}$ to separate the aqueous and organic layers. After separating the organic phase, the extraction procedure was continued on the residual aqueous phase. The ethyl acetate phase was pooled and dried at $60^{\circ} \mathrm{C}$ under a mild stream of nitrogen. After drying, samples were reconstituted with 20 $\mathrm{mL}$ of buffer solution ( $\mathrm{pH} \mathrm{5)}$ and transferred to electrochemical cell for the analysis.

\section{Capsules assay procedure}

The contents of twenty mefenamic acid capsules were weighed and mixed fine. A fractional of powder equivalent to the weight of one capsule was dissolved in $80 \mathrm{~mL}$ ethanol into a $100 \mathrm{~mL}$ volumetric flask. It was sonicated for $20 \mathrm{~min}$ to affect complete dissolution and then made up to volume with ethanol. Suitable aliquots of solution were filtered by a $0.45 \mu \mathrm{m}$ nylon filter. $40 \mu \mathrm{L}$ of the filtered solution was added to a $100 \mathrm{~mL}$ volumetric flask and made up to volume with Britton-Robinson buffer to yield starting concentration of $1000 \mathrm{ng} / \mathrm{mL}$.

\section{Calibration and method validation}

Calibration curves were obtained by plotting anodic peak height against mefenamic acid concentration. Validation parameters including linearity, limit of detection (LOD), limit of quantification (LOQ), precision, accuracy and selectivity were assessed. Square wave voltammograms (SWVs) of mefenamic acid solutions were recorded in a wide range of concentrations $(50-2000 \mathrm{ng} / \mathrm{mL})$ in $\mathrm{pH} 5$ at MWCNTs-G/Ag (1:1, w/w).

\section{Results and Discussion}

\section{Characterization of MWCNTs}

The scanning electron microscopic image of MWCNTs was recorded and shown in Figure 1. In accordance with this Figure 1, MWCNTs have porous structure. Therefore, prepared MWCNTsgraphite mixture can present porous structure. Paraffin oil could bridge the isolated carbon materials in MWCNTs-graphite mixture.

\section{pH effect on voltammetric responses}

The $\mathrm{pH}$ of supporting electrolyte has an important influence on electrochemical response of mefenamic acid at the modified electrode. So, we analyzed the $\mathrm{pH}$ effect of supporting electrolyte on anodic peak

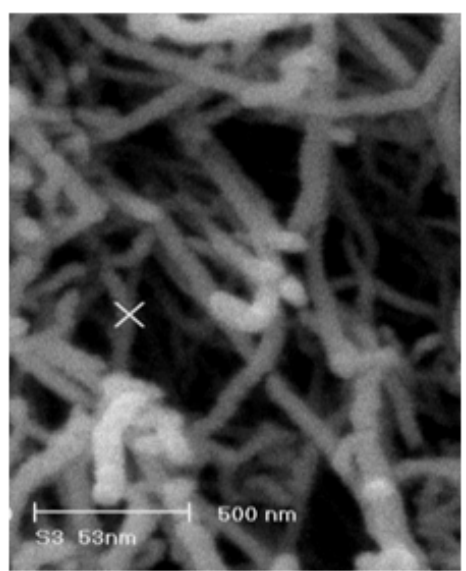

Figure 1: Scanning electron microscopic image of MWCNTs. 
Citation: Moghaddam AB, Mohammadi A, Mohammadi S (2012) Electroanalysis of Mefenamic Acid in Pharmaceutical Formulation and Spiked Biological Fluids on Modified Carbon Nanotube Electrode. Pharmaceut Anal Acta 3:165. doi:10.4172/2153-2435.1000165

currents and potentials to obtain the maximum sensitivity. Cyclic voltammograms (CVs) and square wave voltammograms (SWVs) of mefenamic acid solutions ( $1000 \mathrm{ng} / \mathrm{mL}$ ), were considered in various $\mathrm{pH}$ values from 3.0 to 7.0 . With comparing the electrochemical techniques in different $\mathrm{pH}$, it was found that the square wave voltammetry is a sensitive technique for determination of mefenamic acid. By overlaying CVs and SWVs in different $\mathrm{pH}$ values at MWCNTs-G/Ag electrode, pH 5 was selected as the best pH. Parts (I) and (II) of Figure 2, show CVs and SWVs of mefenamic acid $(1000 \mathrm{ng} / \mathrm{mL})$ in $\mathrm{pH}$ ranges of 3.0 to 7.0 at MWCNTs-G/Ag electrode, respectively. In accordance to part (I) of Figure 2, anodic peaks from $\mathrm{pH} 3$ to 7 show a regularly shifts about $0.05 \mathrm{~V}$ to lower potentials. Inset of this Figure 2 shows the linear relationship between $\mathrm{pH}$ values and anodic peak potentials $\left(\mathrm{E}_{\mathrm{PA}}\right)$ that decreased $56 \mathrm{mV}$ per $\mathrm{pH}$ unit. This relationship can be described by the equation (1):

$$
\mathrm{E}_{\mathrm{PA}}(\mathrm{V})=-0.056 \mathrm{pH}+0.979\left(\mathrm{R}^{2}=0.992\right)
$$

It shows that the equal number of protons and electrons participate in electrochemical oxidation of mefenamic acid. Part (a) of Figure 3, shows the CVs of $1000 \mathrm{ng} / \mathrm{mL}$ mefenamic acid in $\mathrm{pH} 5$ at MWCNTs-G/Ag electrode, while part (b) of this Figure 3, shows the CVs of mefenamic acid at standard glassy carbon electrode. The results show the enhanced electrochemical response of mefenamic acid at MWCNTs-G/Ag electrode compare to glassy carbon electrode. This can be related to the porous structure of MWCNTs-graphite mixture that improves the electroactive surface area.

\section{Effect of scan rate on the peak currents and peak potentials}

The effect of scan rate between $40-300 \mathrm{mV} / \mathrm{s}$ on the electrochemical response of mefenamic acid at MWCNTs-G/Ag electrode was evaluated by cyclic voltammetry that is shown in part (a) of Figure 4. A slope of 0.676 was obtained for the linear relation between the $\log I_{P_{A}}$ and the $\log v$ in part (b) of Figure 4. The regression equation for this relationship is regarding to equation (2):

$$
\log \mathrm{I}_{\mathrm{PA}_{\mathrm{A}}}=0.676 \log \mathrm{v}-1.538\left(\mathrm{R}^{2}=0.996 ; \mathrm{I}_{\mathrm{PA}}: \mu \mathrm{A}, \mathrm{v}: \mathrm{mV} / \mathrm{s}\right)
$$

The slope value of the double logarithmic plot lies in the range from 0.5-1.0 for the mixed adsorption and diffusion controlled process [29]. This result proves that a mixed adsorption and diffusion controlled mechanism was involved in the mefenamic acid oxidation process at the MWCNTs-G/Ag electrode. The results have shown a positive shift in the anodic peak potentials with the increasing of scan rates. Also, in accordance to part (c) of Figure 4, the plot of anodic peak potentials versus the logarithm of scan rates was linear for mefenamic acid oxidation reaction which confirms the irreversibility of oxidation process on the MWCNTs-G/Ag electrode surface. The regression equation for this relation is according to equation (3):

$$
\mathrm{E}_{\mathrm{p}}=39.584 \log \mathrm{v}+614.11\left(\mathrm{R}^{2}=0.998 ; \mathrm{E}_{\mathrm{p}}: \mathrm{mV}, \mathrm{v}: \mathrm{mV} / \mathrm{s}\right)
$$

\section{Calibration curves}

The calibration curves for mefenamic acid were found by the results of square wave voltammetric measurements. We know that the derivative techniques such as square wave voltammetry have a good resolving power and lower background current. The SWVs obtained for mefenamic acid with various concentrations that were linear over the concentration range of $50-2000 \mathrm{ng} / \mathrm{mL}$ as can be seen in Figure 5 . In this Figure 5, anodic current $\left(I_{P_{A}}\right)$ of mefenamic acid were plotted against the concentration of mefenamic acid and linear regression analysis completed on the resulting curve. Three correlation coefficients of $\mathrm{R} 1=0.9989, \mathrm{R} 2=0.9996$ and $\mathrm{R} 3=0.9990$ with R.S.D. values ranging

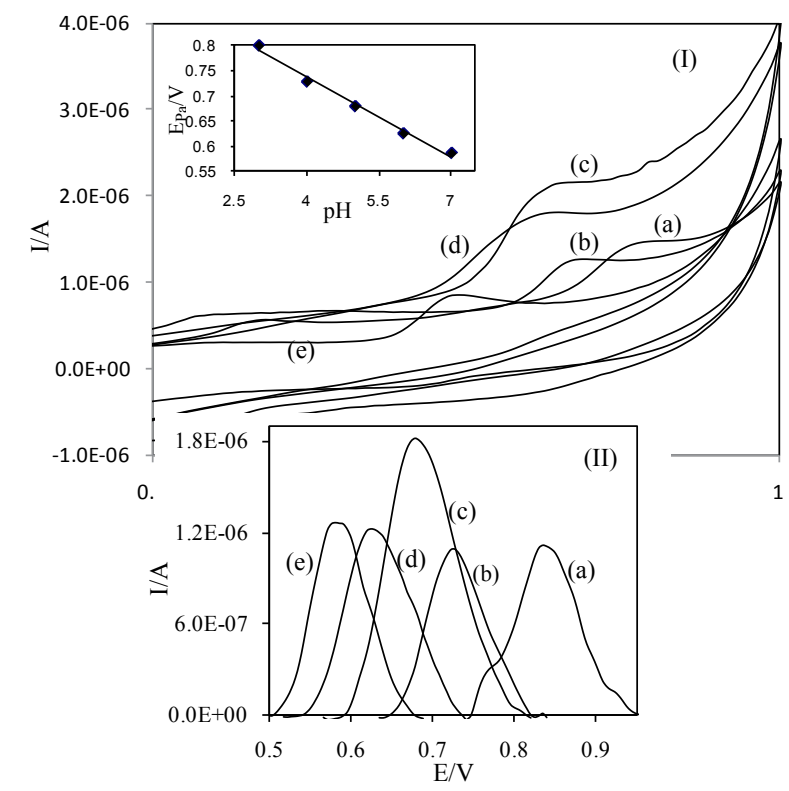

Figure 2: (I) Cyclic voltammograms and (II) square wave voltammograms of $1000 \mathrm{ng} / \mathrm{mL}$ of mefenamic acid at various $\mathrm{pH}$ values (right to left); 3,4 , 5,6 and 7, scan rate: $80 \mathrm{mV} / \mathrm{s}$ at MWCNTs-G/Ag electrode. Inset is the relationship between $\mathrm{pH}$ values and anodic peak potentials.

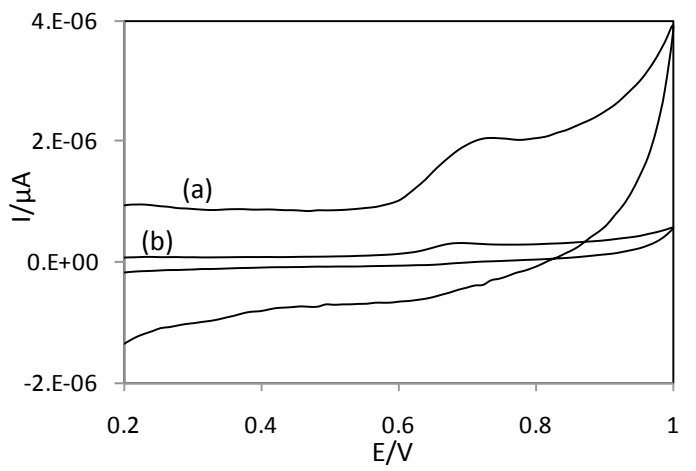

Figure 3: Cyclic voltammograms of $1000 \mathrm{ng} / \mathrm{mL}$ of mefenamic acid (a) MWCNTs-G/Ag electrode (b) glassy carbon electrode.

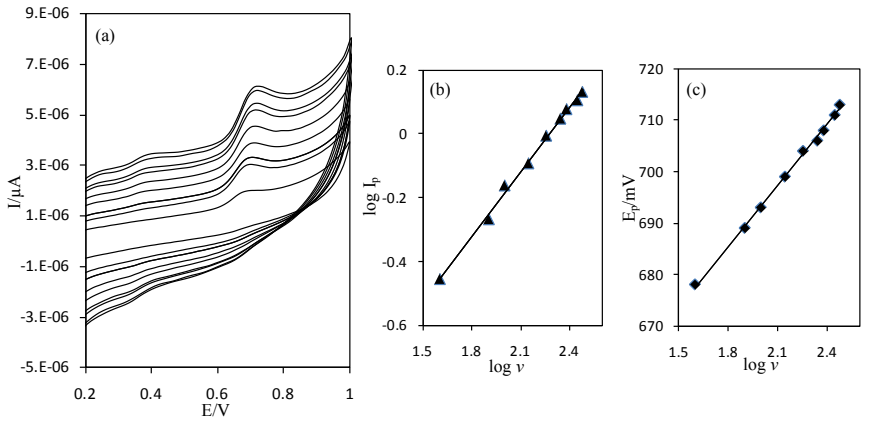

Figure 4: (a) Cyclic voltammograms of $1000 \mathrm{ng} / \mathrm{mL}$ of mefenamic acid at MWCNTs-G/Ag in buffer solution ( $\mathrm{pH} 5$ ) in various scan rates (from inner to outer); 40, 80, 100, 140, 180, 220, 240, 280 and $300 \mathrm{mV} / \mathrm{s}$. (b) Relationship between the peak currents $\left(I_{\mathrm{pa}}\right)$ vs. square root of scan rates (c) Relationship between square root of scan rate and peak potential 
Citation: Moghaddam AB, Mohammadi A, Mohammadi S (2012) Electroanalysis of Mefenamic Acid in Pharmaceutical Formulation and Spiked Biological Fluids on Modified Carbon Nanotube Electrode. Pharmaceut Anal Acta 3:165. doi:10.4172/2153-2435.1000165

Page 4 of 6

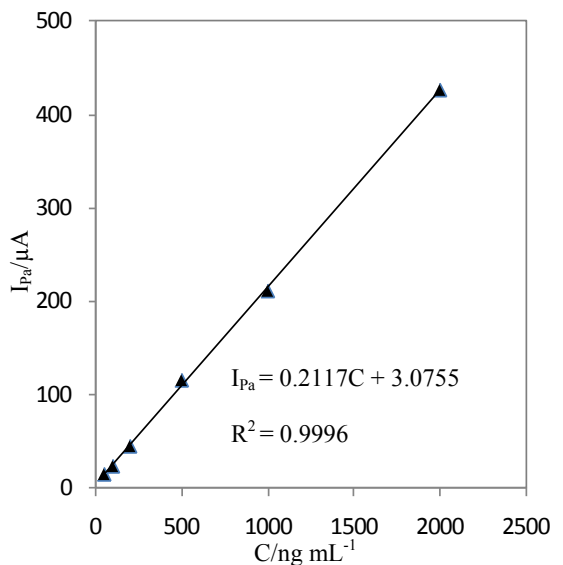

Figure 5: Plot of peak current vs. concentration of mefenamic acid in buffer solution (pH 5) for various concentrations; 50, 75, 100, 200,500, 1000 and $2000 \mathrm{ng} / \mathrm{mL}$

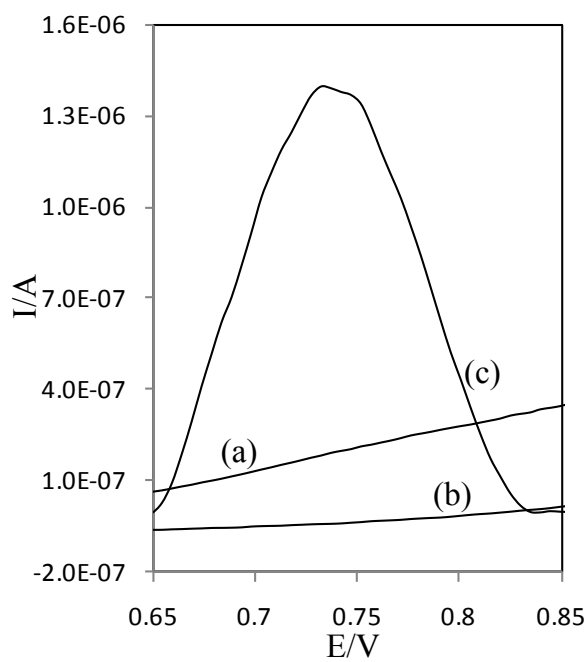

Figure 6: The SWVs of (a) buffer, (b) extracted plasma as a blank and (c) extracted plasma spiked sample $(1000 \mathrm{ng} / \mathrm{mL})$.
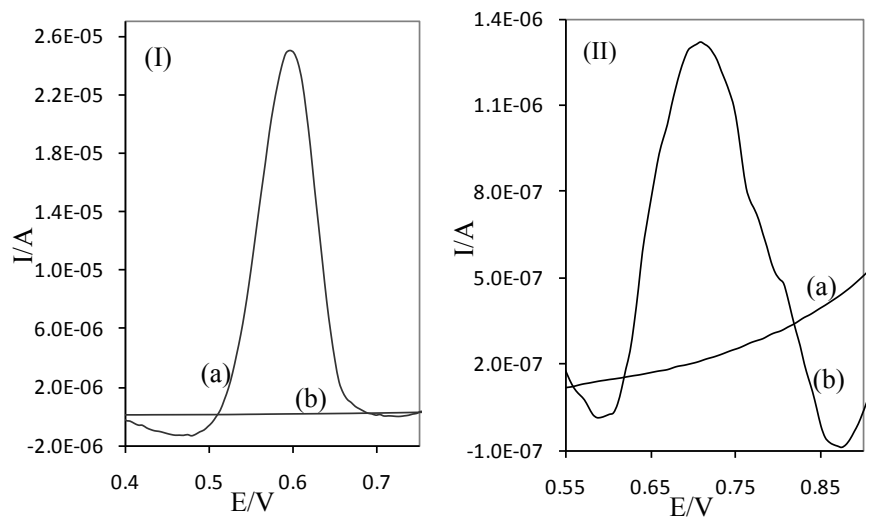

Figure 7: (I) The SWVs of blank urine (a) before extraction, (b) after extraction, (II) The SWVs of (a) urine blank after extraction (b) extracted urine spiked sample $(1000 \mathrm{ng} / \mathrm{mL})$ from 1.6-8 \% across the concentration range studied were obtained. Equation (4) is a typically regression equation for the calibration curve.

$$
\mathrm{I}_{\mathrm{PA}}=0.2117 \mathrm{C}+3.0755\left(\mathrm{R}^{2}=0.9996 ; \mathrm{I}_{\mathrm{PA}}: \mu \mathrm{A}, \mathrm{C}: \mathrm{ng} / \mathrm{mL}\right)
$$

LOQ and LOD of the electrode towards mefenamic acid were found to be $50 \mathrm{ng} / \mathrm{mL}$ and $16 \mathrm{ng} / \mathrm{mL}$, respectively.

Reproducibility for the developed sensor was investigated by electroanalysis of three samples containing 50, 1000 and $2000 \mathrm{ng} / \mathrm{mL}$ standards over 3 consecutive days. The mean concentrations were found to be 46,1000 and $1996 \mathrm{ng} / \mathrm{mL}$ with related \%R.S.D. values of $7.5,3.15$ and 3.1, respectively. Accuracy of the assay was determined by interpolation of replicate $(n=3)$ peak areas of three accuracy standards (50, 1000 and $2000 \mathrm{ng} / \mathrm{mL}$ ) from a calibration curve prepared as previously described. In each case, the percentage of relevant error was calculated. The resultant concentrations were $46 \pm 2.8 \mathrm{ng} / \mathrm{mL}$ (mean $\pm \mathrm{SD}), 1030 \pm 32.4 \mathrm{ng} / \mathrm{mL}$ and $2069 \pm 34.5 \mathrm{ng} / \mathrm{mL}$ with percentage relevant errors of $8.04,3$ and $3.43 \%$, respectively.

\section{Analytical application}

Some voltammetric procedures have been reported for the determination of mefenamic acid in pharmaceutical samples and biological fluids. But in accordance with our knowledge there is no report regarding the use of MWCNTs-G/Ag electrode for the determination of mefenamic acid.

We were determined mefenamic acid with LOD value of $16 \mathrm{ng} / \mathrm{mL}$ by this electrode. In Table 1 the most important reported electrodes are summarized with their LOD for the determination of mefenamic acid.

\section{Assay of mefenamic acid}

The investigated method was applied to the determination of mefenamic acid in a generic brand of mefenamic acid capsules. The result of the assay yielded $103 \%$ (\%R.S.D. $=5 \%$ ) of label claim for the generic brand capsules. The results of the assay indicate that the method is selective for the assay of mefenamic acid without interference from the excipients used in this capsule.

\section{Recovery of mefenamic acid in capsules}

A known amount of mefenamic acid standard was added to aliquots of capsule contents and mixed well. Then the powder was extracted and diluted as previously described to yield a starting concentration of 1200 $\mathrm{ng} / \mathrm{mL}$. This solution was analyzed and the concentration of mefenamic acid was found to be $1225 \pm 51 \mathrm{ng} / \mathrm{mL}$. The resultant \%R.S.D. for this study was found to be $4.16 \%$ with a corresponding percentage recovery value of $102.08 \%$.

\section{Determination of mefenamic acid in human plasma}

Recoveries from human plasma samples were measured by spiking drug-free samples with known amount of mefenamic acid using developed method for determination of mefenamic acid. Parts (a)-(c) of Figure 6, shows the SWVs of buffer, extracted plasma blank and extracted plasma spiked sample $(1000 \mathrm{ng} / \mathrm{mL})$, respectively. It shows that determination of mefenamic acid is accomplished successfully in plasma sample. Three concentrations of mefenamic acid spiked plasma were tested $(200,500$ and $1000 \mathrm{ng} / \mathrm{mL})$. The recovery percentages were summarized in Table 2.

\section{Determination of mefenamic acid in human urine}

Parts (a) and (b) of Figure 7 (I) shows the SWVs of blank urine before and after extraction, respectively. There is a very sharp peak 
Citation: Moghaddam AB, Mohammadi A, Mohammadi S (2012) Electroanalysis of Mefenamic Acid in Pharmaceutical Formulation and Spiked Biological Fluids on Modified Carbon Nanotube Electrode. Pharmaceut Anal Acta 3:165. doi:10.4172/2153-2435.1000165

Page 5 of 6

\begin{tabular}{|l|l|l|l|}
\hline Range of calibration curve & LOD & Electrode type & Reference \\
\hline $384-1525 \mu \mathrm{M}$ & $95.9 \mu \mathrm{M}$ & Nanoparticles of Ni-curcumin-complex modified electrode \\
\hline $25-476 \mu \mathrm{M}$ & $4.96 \mu \mathrm{M}$ & Nickel hydroxide-modified nickel electrode & $\mathbf{1}$ \\
\hline $1-0.01 \mathrm{M}$ & $0.62 \mu \mathrm{M}$ & Mefenamate-sensitive electrode & 19 \\
\hline $0.3-100 \mu \mathrm{M}$ & $0.04 \mu \mathrm{M}$ & Copper (II) doped zeolite modified carbon paste electrode \\
\hline $100-20 \mu \mathrm{M}$ & $10 \mathrm{nM}$ & Carbon nanotubes-gold nanoparticles composite film modified electrode \\
\hline $\begin{array}{l}207-8287 \mathrm{nM} \\
(50-2000 \mathrm{ng} / \mathrm{mL})\end{array}$ & $\begin{array}{l}69 \mathrm{nM} \\
(16 \mathrm{ng} / \mathrm{mL})\end{array}$ & Multi-walled carbon nanotube: graphite/Ag electrode \\
\hline
\end{tabular}

Table 1: Different reported electrodes for determination of mefenamic acid.

\begin{tabular}{|l|l|l|l|}
\hline Spiked mefenamic acid & $200 \mathrm{ng} / \mathrm{mL}$ & $500 \mathrm{ng} / \mathrm{mL}$ \\
\hline $\begin{array}{l}\text { Recovery percent in plasma } \\
\text { (mean } \pm \text { S.D.) }\end{array}$ & $64.5 \pm 2.3$ & $84.7 \pm 1.8$ & $1000 \mathrm{ng} / \mathrm{mL}$ \\
\hline $\begin{array}{l}\text { Recovery percent in urine } \\
\text { (mean } \pm \text { S.D.) }\end{array}$ & $84.2 \pm 1.8$ & $77.65 \pm 1.6$ \\
\hline
\end{tabular}

Table 2: Percent recovery for electrochemical determination of mefenamic acid in plasma and human urine (n=3) by MWCNTs-G/Ag electrode.

near the range of mefenamic acid potential that interferes in the quantitative analysis. Thus the urine blanks were extracted with ethyl acetate. Parts (a) and (b) of Figure 7 (II) shows the SWVs of urine blank after extraction and extracted urine spiked sample $(1000 \mathrm{ng} / \mathrm{mL})$, respectively. Three concentrations of mefenamic acid spiked urine were tested. The recovery percentages were shown in Table 2 .

\section{Conclusions}

The developed methodology offers a new sensitive electrochemical sensor because of high surface area, excellent electrochemical conductivity and electrocatalytic properties of multi-walled carbon nanotubes. MWCNTs-G/Ag electrode resulted in catalytic effects toward the electro-oxidation of mefenamic acid. A remarkable enhancement in microscopic area of the electrode due to the presence of MWCNTs was observed. This caused increasing of the electrooxidation peak current. So, simple and applicable electrochemical sensor allowed the successful determination of mefenamic acid in capsules. It performed directly without any separation steps and also in biological fluids with good recovery percent and RSD.

\section{Acknowledgements}

The financial support provided by the Tehran University of Medical Sciences Research Affairs is gratefully acknowledged. The authors thank the University of Tehran for the supply of some instruments.

\section{References}

1. Gugulothu DB, Fernandes CB, Patravale VB (2012) A versatile high performance liquid chromatography method for simultaneous determination of three curcuminoids in pharmaceutical dosage forms. Pharmaceut Anal Acta 3:156.

2. Hajjizadeh M, Jabbari A, Heli H, Moosavi-Movahedi AA, Haghgoo S (2007) Electrocatalytic oxidation of some anti-inflammatory drugs on a nickel hydroxide-modified nickel electrode. Electrochim Acta 53: 1766-1774.

3. Moffat AC, Osselton DM, Widdop B (2004) Clarke's Analysis of Drugs and Poisons: in pharmaceuticals, body fluids, and postmortem material. 3rd. London: Pharmaceutical Press.

4. Saghatforoush L, Hasanzadeh M, Karim-Nezhad G, Ershadb S, Shadjoua $\mathrm{N}$, et al. (2009) Kinetic study of the electrooxidation of mefenamic acid and indomethacin catalysed on cobalt hydroxide modified glassy carbon electrode. Bull Korean Chem Soc 30: 1341-1348.

5. Madrakian T, Afkhami A, Mohammadnejad M (2009) Second-order advantage applied to simultaneous spectrofluorimetric determination of paracetamol and mefenamic acid in urine samples. Anal Chim Acta 645: 25-29.

6. Aman T, Kazi AA, Mateen B (2005) P-dimethyl amino benzaldehyde as a new chromogenic reagent for the determination of nonsteroidal anti-inflammatory drug by first-order derivative spectrophotometry. Anal Lett 38: 1899-1912.
7. Gómez MJ, Petrović M, Fernández-Alba AR, Barceló D (2006) Determination of pharmaceuticals of various therapeutic classes by solid-phase extraction and liquid chromatography-tandem mass spectrometry analysis in hospital effluent wastewaters. J Chromatogr A 1114: 224-233.

8. Khuhawar MY, Jehangir TM, Rind FMA (2001) Indirect determination of mefenamic acid by atomic absorption spectrometry. J Chem Soc Pakistan 23: 226-228.

9. Husain S, Kifayatullah M, Sekar M (2001) Simultaneous determination of mefenamic acid and paracetamol in pharmaceutical preparations by $1 \mathrm{H}$-nuclear magnetic resonance spectroscopy. Indian J Chem Technol 8: 191-194.

10. Ibrahim H, Boyer A, Bouajila J, Couderc F, Nepveu F (2007) Determination of non-steroidal anti-inflammatory drugs in pharmaceuticals and human serum by dual-mode gradient HPLC and fluorescence detection. J Chromatogr B Analyt Technol Biomed Life Sci 857: 59-66.

11. Jaiswal Y, Talele G, Surana S (2007) Application of HPLC for the simultaneous determination of ethamsylate and mefenamic acid in bulk drugs and tablets. $J$ Liquid Chromatogr Relat Technol 30: 1115-1124.

12. Jaiswal YS, Talela GS, Surana SJ (2005) Quantitative analysis of ethamsylate and mefenamic acid in tablets by use of planar chromatography. J Plan Chromatogr Modern TLC 18: 460-464.

13. Hopkala H, Pomykalski A (2004) TLC analysis of non-steroidal anti-inflammatory drugs and videodensitometric determination of fenbufen in tablets. J Plan Chromatogr Modern TLC 17: 383-387.

14. Mikami E, Goto T, Ohno T, Matsumoto H, Inagaki K, et al. (2000) Simultaneous analysis of anthranilic acid derivatives in pharmaceuticals and human urine by high-performance liquid chromatography with isocratic elution. J Chromatogr B Biomed Sci Appl 744: 81-89.

15. Garcia S, Pedreno CS, Albero I, Garcia C (2001) Flow-injection spectrophotometric determination of diclofenac or mefenamic acid in pharmaceuticals. Microchim Acta 136: 67-71.

16. Zisimopoulos EG, Tsogas GZ, Giokas DL, Kapakoglou NI, Vlessidis AG (2009) Indirect chemiluminescence-based detection of mefenamic acid in pharmaceutical formulations by flow injection analysis and effect of gold nanocatalysts. Talanta 79: 893-899.

17. Mohammadi A, Moghaddam AB, Hosseini S, Kazemzad M, Dinarvand R (2011) A norepinephrine biosensor based on a glassy carbon electrode modified with carbon nanotubes. Anal Methods 3: 2406-2411.

18. Mohammadi A, Moghaddam AB, Ahadi S, Dinarvand R, Ali A (2011) Application of cobalt oxide nanoparticles as an electron transfer facilitator in direct electron transfer and biocatalytic reactivity of cytochrome $c$. J Appl Electrochem 41 115-121.

19. Babaei A, Khalilzadeh B, Afrasiabi M (2010) A new sensor for the simultaneous determination of paracetamol and mefenamic acid in a pharmaceutical preparation and biological samples using copper(II) doped zeolite modified carbon paste electrode. J Appl Electrochem 40: 1537-1543.

20. Mohammadi A, Moghaddam AB, Kazemzad M, Dinarvand R, Badraghi J (2009) Synthesis of nickel oxides nanoparticles on glassy carbon as an electron transfer facilitator for horseradish peroxidase: Direct electron transfer and $\mathrm{H}_{2} \mathrm{O}_{2}$ determination. Mat Sci Eng C 29: 1752-1758. 
Citation: Moghaddam AB, Mohammadi A, Mohammadi S (2012) Electroanalysis of Mefenamic Acid in Pharmaceutical Formulation and Spiked Biological Fluids on Modified Carbon Nanotube Electrode. Pharmaceut Anal Acta 3:165. doi:10.4172/2153-2435.1000165

21. Moghaddam AB, Ganjali MR, Dinarvand R, Norouzi P, Saboury AA, et al. (2007) Electrochemical behavior of caffeic acid at single-walled carbon nanotube:graphite-based electrode. Biophys Chem 128: 30-37.

22. Moghaddam AB, Ganjali MR, Niasari M, Ahadi S (2008) Bioelectrocatalysis of dopamine using adsorbed tyrosinase on single-walled carbon nanotubes. Anal Lett 41: 3161-3176

23. Moghaddam AB, Ganjali MR, Dinarvand R, Ahadi S, Saboury AA (2008) Myoglobin immobilization on electrodeposited nanometer-scale nickel oxide particles and direct voltammetry. Biophys Chem 134: 25-33.

24. Wang $\mathrm{H}$, Zhang A, Cui $\mathrm{H}$, Liu D, Liu R (1998) Adsorptive stripping voltammetric determination of phenol at an electrochemically pretreated carbon-paste electrode with solid paraffin as a binder. Microchem J 59: 448-456.

25. Moghaddam AB, Ganjali MR, Dinarvand R, Razavi T, Riahi S, et al. (2009)
Fabrication and electrochemical behavior of single-walled carbon nanotube/ graphite based electrode. Mat Sci Eng C 29: 187-192.

26. Dai Z, Xu X, Ju H (2004) Direct electrochemistry and electrocatalysis of myoglobin immobilized on a hexagonal mesoporous silica matrix. Anal Biochem 332: 23-31.

27. Jayasri D, Narayanan SS (2007) Amperometric determination of hydrazine at manganese hexacyanoferrate modified graphite-wax composite electrode. J Hazard Mater 144: 348-354.

28. Tsierkezos NG, Ritter U (2010) Synthesis and electrochemistry of multiwalled carbon nanotube films directly attached on silica substrate. J Solid State Electrochem 14: 1101-1107.

29. Mohammadi A, Moghaddam AB, Dinarvand R, Badraghi J, Atyabi F, et al (2008) Bioelectrocatalysis of methyldopa by adsorbed tyrosinase on the surface of modified glassy carbon with carbon nanotubes. Int J Electrochem Sci 3: 1248-1257. 